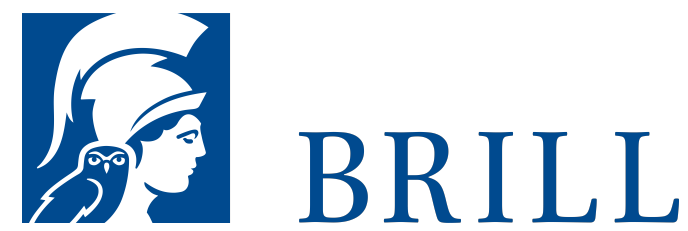

\title{
Individuelle Verantwortung für kollektiv verursachte Übel
}

\section{Author: Sabine Hohl}

Sollten Individuen angesichts des drohenden Klimawandels ihre persönlichen Treibhausgasemissionen einschränken? Ist es moralisch problematisch, ein unter ungerechten Arbeitsbedingungen produziertes Kleidungsstück zu kaufen? Die Beantwortung dieser Fragen hängt davon ab, inwiefern wir als Individuen für moralische Übel mitverantwortlich sind, die durch eine Vielzahl von Akteuren gemeinsam verursacht werden. Die Herausforderung für eine Begründung individueller Verantwortung besteht darin, dass Handlungen wie das Fahren eines Autos mit hohem Treibhausgasausstoß oder der Kauf eines unter ungerechten Bedingungen hergestellten Kleidungsstücks scheinbar keinen Einfluss auf die relevanten Übel haben: Ob ich als Individuum diese Handlungen ausführe oder nicht, ändert - so scheint es - nichts am kollektiven Ergebnis, und so entsteht der Eindruck, dass die Basis für die Zuschreibung moralischer Verantwortung fehlt. In diesem Buch wird gezeigt, dass Individuen zu kollektiv verursachten Übeln in einer Weise beitragen, die moralische Verantwortung begründet. Zudem wird diese auch dadurch nicht aufgehoben, dass andere Akteure nicht bereit sind, Beitragshandlungen zu Übeln zu unterlassen.

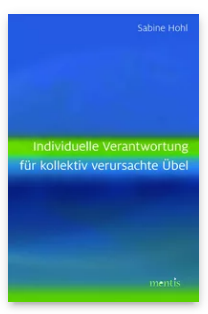

Pages: 169 Seiten

Language:

German

Subjects:

General, Philosophy

Publisher: Brill | mentis

E-Book (PDF)

Released online:

o1 Feb 2017

ISBN: $978-3^{-}$

95743-807-2

List price

Paperback

Publication date: o1 Feb 2017

ISBN: 978-3-

95743-075-5

List price 
For more information see brill.com

Order information: Order online at brill.com +44330 333 0049 | customerservices@brill.com Submission information: brill.com/authors

Titles published by Brill | Fink, Brill | mentis or Brill | Schöningh: +49(o)715413279216| brill@brocom.de 